\title{
Towards a Comprehensive Health Care: Human Rights Approach (Letter)
}

G. P. Taranyuk (Gennadiy P. Taranyuk)

Association of Palliative and Hospice Care

Original Article

\section{E-mail address:}

elpidiagp@gmail.com

\section{Reprint address:}

Gennadiy P. Taranyuk

Kiev Medical University, Department of Phisiology, Byophysics, Byochemistry and Medical biology, Senior lecturer

9, Lev Tolstoy St.

Kyiv 01004

UA

Suource: Clinical Social Work and Health Intervention

Volume: 8

Issue: 4

Pages: $89-91$

Cited references: 6

\section{Reviewers:}

Jirina Kafkova

St. Bakitha Clinic, Nairobi, Kenya

Selvaraj Subramanian

SAAaRMM, Kuala Lumpur, Malaysia

\section{Key words:}

Health. Illness. Health needs. Social environment. Biopsychosocial equilibrium. Human rights. Quality of life.

\section{Publisher:}

International Society of Applied Preventive Medicine i-gap

CSWHI 2017; 8(4): 89 - 91; DOI 10.22359/cswhi_8_4_12 @ 2017 Clinical Social Work and Health Intervention

\section{Abstract:}

Health needs (in all points of this notion) should be identified as previously listed vitally important human needs and/or a vice versa. The right to life is equal to the person's right to being included in society; to being protected and supported; to have access to collective goods. Human rights concept should be seen as a key point of Public Health and must play the role of methodological platform for comprehensive healthcare. 


\section{To the Editors}

The aim of our research was to analyze, in what measure, is the Human Rights Approach a methodological basis for providing of comprehensive health care: A pilot study using an analysis of web-sites, articles, experts, interviews.

It is well-known that illness affects a person mentally and socially in no less degree then it affects his/her physiological nature. It is also known that the biological, psychosocial and cultural domain of human beings influence each other in a strong interrelated manner. This notion leads to understanding of the social environment as an active agent of health forming and health-illness relationships. Moreover, society turns out to be the only system which is capable of satisfying a wide range of vitally important human needs corresponding with maintaining homeostasis and including feeding; clothing; housing; life protected artificial means and social infrastructure to provide, support and facilitate health, and which have been created and utilized on a collective base.

Besides that, according to numerous studies in the same arena of fundamental human needs are placed psychosocial needs. These are belongingness needs (attachment needs) (J. Bowlby); safety needs (the need for ordered, properly ruled and predictable course of life and social relationships); the esteem needs; the needs in self-actualization (A. Maslow) which are also, as it was shown, facilitate homeostasis or biopsychosocial equilibrium in a wider social and cultural context; that actually means that biological adaptation and social (norms-values) adaptation go together (E. Durkheim, R. Merton, R. Fogel, R. Wilkinson).

Such a vision opens a new dimension for analyses of health-illness relations with respect to human rights; as well as quality of life concepts in Public Health discourse.

Indeed, from these above mentioned, derives the concept that health needs (in all points of this notion) should be identified, as previously listed, vitally important human needs and/or a vice versa. Hence, the health care might to be seen as a care which is addressed to basic human needs. Nevertheless, health care is still associated with medical care and meets basic human needs (health needs) only partially making stress predominantly on disease and its somatic issues.

At the same time, human rights, namely the right to life, is essentially the right to satisfy vitally important needs which are directly related with social relationships; social inclusion; social norms and values. In other words, the right to life is equal to the person's right to being included in society; to being protected and supported; to have access to collective goods. From another side it means for a person to be attached; to be loved; to have the possibility to unfold his/her own personality in social roles performing, doing what he or she is fitted for. In turn, it means that poverty; low living standards; psychosocial stresses caused by inequalities of all kinds; as well as anomy (little moral guidance); social exclusion; lack of social cohesion carries permanent health risks and must be considered in the context of human rights violations.

In case of disease a person faces similar risks. Even innocent disorder is able to unsettle a person's life course; not to mention the more serious cases threatening death; irreversible functional disabilities; social exclusion which as it already has been noted contains the same hazards and provokes further development of disease.

For this reason, the qualitative and quantitate evaluation impact of disease and a person's health status measurements denote the set of variables describing the physical, social and mental functioning of a person with reference to quality of life and wellbeing, and which could be interpreted as one may conclude in the human rights framework. 
Therefore, the concepts of human rights; quality of life; health needs should be considered in one functional plan.

Namely, the rights of the needy person must be analyzed in light of the quality of life and efficiency of care received by him; undertaken medical and social measures; its efficiency should be evaluated under the eye of human rights and to what extent it contributes to improving of quality of life; evaluation of the quality of life requires appealing to the person's capacity to realize his/her own rights.

In practice, such an approach could be represented with the follow procedures:

A) Evaluation of a person's actual health status.

B) Identification of disease/social environment impact, namely unsatisfied basic vital needs articulated due to disease and/or external circumstances, or subjected to its influence.

C) Identification of activities/measures which have to be undertaken in order to protect a person from negative somatic and psychosocial influences of disease; or which are able to compensate them.

D) Revealing the links between activities should to be undertaken and institutional tools in providing of human rights referred with particular vital needs. This point should make a clear distinction between human rights and patient rights concepts. The "patient's rights" is an important but institutionally restricted notion which must not be a substitute for the generalized and universal concept of human rights.

The above considerations could be summarizing with the following conclusion:

Human rights concept should be seen as a key point of Public Health and must play the role of methodological platform for comprehensive health care.

\section{References}

1. BOWLBY J (1940) The influence of early environment in the development of neurosis and neurotic character/John Bowlby//. International Journal of Psycho-Analysis 1. P. $154-178$.

2. BOWLBY J (1969) Attachment and Loss. Volume I. Attachment / John Bowlby. - London: Hogarth Press- 399 p.: xxxvi.

3. MASLOW A (1954) Motivation and Personality / A. H. Maslow. - Harper \& Row Publishers Inc. 369 p.: XXX.

4. MERTON RK (1966) Social Theory and Social Structure / Robert K. Merton New York: The Free Press, 709 p.: XXIII.

5. FOGEL RA (1997) Theory of technophysio evolution, with some implications for forecasting population, healthcare costs and pension costs / Robert W. Fogel, Dora L. Costa // Demography. 34.- P. 49 - 66.

6. FOGEL RW (2004) The Escape from Hunger and Premature Death 1700-2100: Europe, America, and the Third World / Robert William Fogel. - Cambridge, New York, Melbourne, Madrid, Cape Town: Cambridge University Press,. - 196 p.: xx. 